\title{
The Relationship between Sharia Supervisory Board and External Auditor: Evidence from Jordan
}

\author{
Dr. Raed Jameel Jaber ${ }^{1}$, Dr. Abdullah Ibrahim Nazal ${ }^{2}$ \\ Zarqa University, Jordan
}

\begin{abstract}
This study is one of very few studies which had investigated Islamic Bank disclosure by showing Relationship between Sharia Supervisory Board (SSB) and External Auditor (EA) in Islamic Banks. It takes Jordanian Islamic banks as a case study. It found that there are three types of relationship which are: Isolation, A Step by Step Approach, and Duplication of work. There is a need to apply a proposed model which show centralization and standardization of services based on Islamic Rules as approved by SSB. This model will help the EA to review the accounting data and accept the financial statements on the basis of Islamic rules, so that there will be a full commitment to Islamic accounting standards. There are some limits to the practical application as a result of globalization environment. Researchers recommended applying the proposed model after avoiding the limits.
\end{abstract}

Keywords: Islamic Bank, Sharia Supervisory Board (SSB), External Auditor(EA), Islamic Rules, Relationship and Financial Statements.

\section{INTRODUCTION}

Islamic banks do not deal with loan interest whether in investing or in financing as a result to Islamic rules. It has a different environment from a legal point depending on the different law in the country. Some countries give the traditional bank the right to sell Islamic services beside traditional services. Central Bank of Jordan applies specialized law of Islamic banks to avoid non Islamic services. It obligates the Islamic banks to give annual report every year which includes Sharia Supervisory Board (SSB) report and External Auditor's Report.

SSB is assigned by Shareholders' General Meeting to prove that dealing of service meets the Islamic Rules. There is responsibility on SSB to clarify that Islamic bank services are completely complying with Islamic rules, also there is responsibility on External Auditor (EA) to clarify that financial statements and results of the bank are complying with the Accepted Accounting Standards, beside Islamic rules as approved by the SSB of the bank.

Islamic banks offer their services to all citizens as a Public Joint-Stock Companies. They need appropriate disclosure because of the huge services provided in many branches all over the country. This comes as a result to the separation of ownership from management, so they need information to evaluate their investments in the Islamic bank. (Sadique, 2009) showed that the partner must accept a percentage of profits based on the value of his shares in the bank. Customers need assurance to get Islamic services in accordance with Sharia Law (Munusamy, Chelliah, \& Mun, 2010). Employees, creditors, and central bank need to evaluate their returns. Government provides the necessary support to encourage banks and development of the banking sector, also it gets taxes from banks as income tax, which equal (35\%-45\%)to finance its general budget. Practically, all users need disclosure, so the Islamic Bank must provide the required disclosure showing the Sharia commitment, through the report of each of the SSB and the EA.

\section{Methodology}

\subsection{The Study Problem}

The research problem is to determine the nature of the relationship between Sharia Supervisory Board (SSB) and External Auditor (EA) in Jordanian Islamic banks; to ensure the achievement of the objectives of both parties. The problem questions are: 
a) What is the importance and responsibility of SSB report and EA report in Jordanian Islamic banks?

b) What are the different types of relationship between the SSB and EA in the Jordanian Islamic banks, and what is the effect of each of them?

c) What is the proposed model for the relationship between the SSB and EA in the Jordanian Islamic banks?

\subsection{The Study Objectives}

The main objective of this research is to determine the relationship between SSB and EA in Jordanian Islamic banks. This can be done through the following steps:

a. Determining the importance and responsibility of SSB report and External Auditor's report.

b. Determining the effect of the relationship types between SSB and EA in different Islamic banks.

c. Trying to propose a model for the relationship between SSB and EA in Jordanian Islamic banks.

\subsection{The Study Importance}

This research is important because it shows the relationship between SSB and EA in the environment of Jordanian Islamic banks. It discusses the factors which effect on disclosure in accordance with Islamic banks' law. It will help shareholders, customers, creditors, suppliers, employees and government to achieve their aims. It also discusses the types of relationship between SSB and EA and gives practical suggestions to activate the control system in the Jordanian Islamic banks.

\section{LITERATURE REVIEW}

There were many studies that discussed Sharia Audit in Islamic banks, as (Mulyany and Hameed, 2009) discussed Islamic audit for Islamic Financial Institutions in Malaysia. It found that there is need to make systematic development of the discipline Sharia audit. It required accounting and auditing techniques beside sharia audit standardization, which should work to direct the applications of Accounting and Auditing Organization for Islamic Financial Institutions (AAOIFI). (Aisah, Muhammadun, Shahimi and Shaffii, 2015) discussed competency framework for Sharia auditors in Malaysia and they found that it has not developed yet. They suggest KSOC Model (Knowledge, Skills and other Characteristics). (Ahmed \& Hussainey, 2015) investigated the conventional banks conversion into Islamic Banks.It suggested the application of specific conditions and to be fully committed to Sharia Law.(Atmeh \& Abu Serdaneh, 2012) discussed the accounting treatment of Ijarah offered by AAOIFI, they pointed out that it did not achieve matching principle and lacked equitable representation, and they suggested amendments to the accounting treatments.(Perry \& Rehman, 2011) evaluated Islamic banking after it works in the west. He found that it is weakness to be a system because of traditional bank competition, but crises will help in the success expansion of Islamic bank industry as a way to manage risk by Islamic rules. (Elsiefy, 2013) focused on the differences between Islamic banks and Traditional banks before, during and after the financial crises in 2008 by using financial ratios. There were differences in liquidity, credit, risks, profitability and solvency.

\section{ANALYSIS AND DiscuSSION}

\subsection{Importance and Responsibility of Sharia Supervisory Board Report and External Auditor's Report in Jordanian Islamic Banks}

Islamic rules must control all contracts, the basic contracts, adjusted and developed contracts. These types may contain additional or less conditions; to meet the banks interests and customers' needs in different times or places. This gives flexibility to the financing structure, investment structure and management structure (Abdullah, 2006).

Jordan Islamic Bank and Islamic International Arab Bank are Jordanian local Islamic banks. Each of them must give annual report include SSB report and External Auditor's report. SSB gives its opinion based on Islamic Rules and Sharia Audit of the contracts and services. EA gives his opinion based on 
the review and investigation of the accounting data that appear in the closing financial statements. Practically, the responsibility for the application of contracts in accordance with Islamic Rules and Accounting Principles depends on staff .SSB and EA give their opinions based on their experiences in review, investigation and evidence collection. They face many contracts, many services and many accounting data. They use a sample of them, beside verification of the problems of Islamic banks in court, and examination of other subsequent events to prepare their reports.

Each of (Islamic International Arab Bank Annual Report, 2014) and (Jordan Islamic Bank Annual Report, 2015) showed that the EA is responsible for auditing the financial statements based on the audit standards issued by AAOIFI. The EA will check financial data, documents, accounting procedures, Accounting Polices, accounting evaluation and the impact of Islamic rules on financial statements. These Islamic rules must be approved by SSB. The importance of EA comes as a result of his role in the discovery of material deviations or mistakes in accounting, as well as financial frauds and trickery. These reports showed that the bank's management is responsible for application services with a full commitment to Islamic rules. On the other hand, the SSB will work on the follow-up and verification of any problems facing the Islamic bank's management to ensure the Sharia commitment.SSB must resolve any problem in the implementation of contracts or applying nonIslamic rules. As a result, each of the SSB and the EA does not arrive to the absolute assurance of $100 \%$, and typically they are giving a clean report on the financial statements. SSB importance comes as a result of showing Islamic rules for all services, contracts, conditions, procedures, documents, grantees, Insurances, resources of fund, returns and distributed of returns.

\subsection{The Impact of Relationship Types between SSB and EA in Different Islamic Banks}

Identification and allocation of responsibilities between SSB and EA could not be clear as in (Islamic International Arab Bank Annual Report, 2014). It showed that SSB audits the balance sheet and income statement; in order to obtain a reasonable assurance about the application of Islamic rules. Also it showed that EA audits the balance sheet and income statement; in order to obtain a reasonable assurance about the financial position and the result of income in accordance with Islamic rules. This situation shows a conflict of tasks between SSB and EA. This means that there is a problem in the structure of work between the functions of each of them. In practice, this relationship will cause a problem of responsibility for both of them when they find mistakes or trickery.

This case needs to be discussed. What are the expected relationship types between SSB and EA in different Islamic banks?

The expected relationship types are three types which are:

\subsubsection{First Type: Isolation}

In Isolation, EA has to give a report based on verification of the accounting data, accounting explanations, accounting documents and evidences. In this type the auditor should perform all procedures separately from the SSB.

This case shows Isolation between SSB and EA.The result of Isolation shows that accounting data is fixed because of ignoring Islamic rules.

What is the impact of missing the relationship between SSB and EA?

When relationship become missing, the disclosure of accounting data will be in a very weak case. As a case study, Murabaha is a selling contract. It has Islamic rules and accounting data as a basic contract, adjusted contract and developed contract. Suppose the Islamic Bank sign the promise contract with customer to buy a car. It costs in market $10000 \$$ including all costs. Then the Islamic bank sign the contract to sell customer this car with a return equal $1000 \$$ (The selling price $=11000 \$$ ) and customer will pay 5 installments of the amount (11000\$) to own this car. Customer will get the car after signing the selling contract and he will use it until he pays the $11000 \$$.Case of Isolation will show a different accepted accounting data as in the next table: 
Table1. Murabaha service in case of Isolation between SSB and EA

\begin{tabular}{|c|c|c|c|}
\hline The case & $\begin{array}{c}\text { The Impact of Islamic Rules on cost } \\
\text { of contract }\end{array}$ & $\begin{array}{l}\text { The Impact of } \\
\text { Islamic Rules on } \\
\text { accounting data }\end{array}$ & $\begin{array}{c}\text { Case of Isolation : } \\
\text { The Impact of Isolation } \\
\text { on accounting data } \\
\text { (Without taking into } \\
\text { consideration the Islamic } \\
\text { rules) } \\
\end{array}$ \\
\hline $\begin{array}{l}\text { Case 1:The bank asks the } \\
\text { customer to find the car } \\
\text { and to buy it after the } \\
\text { bank gave him } \\
\text { authorization and check } \\
\text { equal 10000\$ }\end{array}$ & $\begin{array}{l}\text { The Bank is not exposed to any risk. It } \\
\text { gives a check of acertain amount } \\
\text { (loan) to customer, and it gets the } \\
\text { interest on the loan amount as a profit } \\
\text { (1000\$) .It is interest on loan (Reba) } \\
\text { and the contract must be cancelled. }\end{array}$ & $\begin{array}{l}\text { Zero (The contract } \\
\text { does not include } \\
\text { commitment to the } \\
\text { Islamic rules) }\end{array}$ & $\begin{array}{c}* \text { Cost of Contract }- \text { for } \\
\text { customer }=10000 \$+ \\
1000 \$(\text { profit })=11000 \$ \\
\text { divided on } 5 \text { installments }\end{array}$ \\
\hline $\begin{array}{l}\text { Case 2: The Bank has a } \\
\text { special agency to buy a } \\
\text { car for the customer, it } \\
\text { costs the bank } 8,000 \text { \$and } \\
\text { includes all costs }\end{array}$ & $\begin{array}{c}\text { The cost of contract- for customer }= \\
8000 \$+1000 \$(\text { Profit })=9000 \$ \\
\text { because It's a secretariat contract } \\
\text { which must show the real costs and } \\
\text { the profit. }\end{array}$ & $\begin{array}{l}9000 \$ \text { divided on } 5 \\
\text { installments }\end{array}$ & $\begin{array}{c}* \text { Cost for customer }= \\
10000 \$+1000 \$(\text { profit }) \\
=11000 \$ \text { divided on } 5 \\
\text { installments }\end{array}$ \\
\hline $\begin{array}{l}\text { Case 3: The bank bought } \\
\text { the car and paid } 8000 \$ \text {. } \\
\text { Car accident occurred } \\
\text { just before delivery to the } \\
\text { customer. The repairing } \\
\text { cost is } 500 \$ \text { to get its } \\
\text { real value. }\end{array}$ & $\begin{array}{l}\text { The cost for customer in case } 2= \\
8000 \$+1000 \$ \text { (Profit) }=9000 \$, \text { but } \\
\text { because it is a secretariat contract, it } \\
\text { must show the real costs and the } \\
\text { profit. The bank has to add } 500 \$ \text { as } \\
\text { cost of repairing to the other costs and } \\
\text { it has to reduce it from its profit; } \\
\text { because the bank should bear the risk. } \\
\text { The cost will be }=8000 \$+500 \$ \\
\text { (repairing) }+500 \$(\text { profit) }=9000 \$\end{array}$ & $\begin{array}{l}9000 \text { \$ divided on } 5 \\
\text { installments }\end{array}$ & $\begin{array}{c}* \text { Cost for customer }= \\
10000 \$+500 \$(\text { repairing) } \\
+1000 \$ \text { (profit) }=11500 \$ \\
\text { divided on } 5 \text { installments }\end{array}$ \\
\hline $\begin{array}{l}\text { Case 4: The bank gave } \\
\text { the car after repairing to } \\
\text { customer .As a result to } \\
\text { liquidity or to transfer } \\
\text { customer default risk, the } \\
\text { banks old the Murabaha } \\
\text { contract with other } \\
\text { Murabaha contract, as } \\
\text { investing certificates in } \\
\text { the financial Market. The } \\
\text { price which was received } \\
9000 \$=8000 \$+500 \$ \\
\text { (repairing) }+500 \$ \\
\text { (profit). }\end{array}$ & $\begin{array}{l}\text { The contract of Murabaha installments } \\
\text { includes delay buying. It is a loan on } \\
\text { the customer. Selling loan with } \\
\text { discount is not accepted and the } \\
\text { contract of investing certificates must } \\
\text { be cancelled. }\end{array}$ & Zero & $\begin{array}{c}* \text { Cost for customer } \\
=10000 \$+500 \$ \\
\text { (repairing) }+1000 \$ \\
\text { (profit) }=11500 \$ \text { divided } \\
\text { on } 5 \text { installment }\end{array}$ \\
\hline $\begin{array}{l}\text { Case 5: the bank gave the } \\
\text { car after repairing to } \\
\text { customer. After the } \\
\text { customer had got the car } \\
\text { he made accident, as a } \\
\text { result, the car lost } 1000 \$ \\
\text { of its fair value. }\end{array}$ & $\begin{array}{l}\text { The cost for customer }=8000 \$(\text { cost } \\
\text { for bank })+500 \$ \text { (repairing }) \\
+500 \$(\text { profit })=9000 \$\end{array}$ & $\begin{array}{l}9000 \$ \text { for } 5 \\
\text { installments }\end{array}$ & $\begin{array}{c}* \text { Cost for customer } \\
=10000 \$+500 \$ \\
\text { (repairing) }+1000 \$ \\
\text { (profit) }=11500 \$ \text { divided } \\
\text { on } 5 \text { installment }\end{array}$ \\
\hline $\begin{array}{l}\text { Case 6: The customer got } \\
\text { in default. }\end{array}$ & $\begin{array}{l}\text { There will not be any added amount } \\
\text { on price for customer; because it is } \\
\text { fixed ( } 9000 \$) \text {. }\end{array}$ & $\begin{array}{l}9000 \$ \text { for } 5 \\
\text { installments }\end{array}$ & $\begin{array}{c}* \text { Cost for customer } \\
=10000 \$+500 \$ \\
\text { (repairing) }+1000 \$ \\
\text { (profit) }=11500 \$ \text {. } \\
\text { The bank will add } 50 \$ \text { (for } \\
\text { ex.) as a result to the delay } \\
\text { of payment . The total cost } \\
\text { will equal } 11550 \$ \text { divided } \\
\text { on } 5 \text { installments. }\end{array}$ \\
\hline
\end{tabular}

Source: prepared by searchers

*Note: there are clear differences in the results related to cost of contract (Murabahah) for the customer in two columns (3, 4): The Impact of Islamic Rules and Case of Isolation. 
As a result to Isolation between SSB and EA, there will be different results of accounting data which are not accepted by customer in Islamic rules. Customers will ask SSB about the extent of the Sharia commitment in the contract, and then they have a gap in management. Practically, customer is the weak point.SSB has not enough independence in its decisions or advisory opinions, where they are often influenced by the bank's management trends.

\subsubsection{Second type: A Step by Step Approach}

The first step is: SSB has to give acceptable report of applying Islamic rules in the Islamic bank. Then, the EA has to give a report based on accounting data in the second step. This case shows there is a relationship based on arrangement of two steps between SSB and EA. The Impact of arrangement shows that accounting data will not be accepted from EA until there is an acceptance from SSB.

\subsubsection{Third Type: Duplication of Work}

EA should know the Islamic rules and also accounting principles, and SSB should know the Islamic rules and also accounting principles. There is an overlap in tasks between the EA and the SSB. Each of them must give a report indicating the acceptance of financial statements of the Islamic bank in accordance with Islamic rules, and accounting principles. The Impact of Duplication shows that there is no relationship between SSB and EA, so each of them must give two acceptances: 1-an acceptance for Islamic rules' report, and 2- other acceptance for accounting and auditing' report.

\section{Conclusions, Limitations AND RECOMMENDATIONS}

\subsection{Conclusions}

There is importance to show the responsibility of SSB and EA in Jordanian Islamic banks to avoid overlapping tasks. Practically, relationship types between SSB and EA are: Isolation, A Step by Step Approach, and Duplication of work. The proposed model for the relationship between SSB and EA in Jordanian Islamic banks depends on real application of Islamic Sharia law.

If the Islamic bank applies Islamic rules, the result of accounting data will be accepted from customers, and if the SSB cancels the contract there will not be accounting data for this contract. As a result of this case, some frauds occurred. For example: Employee applies a contract with customer without commitment of Islamic rules. In this case, the contract must be canceled, revenue will not be recognized and it will be considered as illegal. Profits come from this contract will be isolated from the bank's profits, and they will be distributed in charity works.

The proposed model of relationship depends on twosteps:1-SSB must issue special contracts to all services in the bank, and the use of these contracts must be mandatory for all employees. The bank's management must punish any employee mistake or manipulate in the implementation of contracts; in order to centralize every service and its classifications. The obligated conditions (contracts) will include different customers need basic contracts, improved contracts and developed contracts. Standardization of each contract is a suitable way to give employee a solution to deal with many customers and getting same benefit. Standardization will rule employee. If there is a specialized type of contract, it must be done directly by SSB to meet Islamic rules. 2- The financial statements must be audited by EA after the SSB has agreed the contracts of services in order to meet success accounting results (A Step by Step Approach).

Disclosure in Financial Statements could be applied locally or internationally and may be changed from time to time as a result to change in accounting standards. It will effect on company's financial report and may show different accounting data (Richard, Myrite and Jack, 2011). The problem comes as a result of the application of Islamic accounting standards that may not coincide with International Accounting Standards. Obligated conditions (contracts) which we have mentioned may be applied by Traditional Central Bank or by international standards. The researchers believed that the use of atypical contracts in the proposed mechanism may be an appropriate solution to the overlapping of tasks between EA and SSB. Moreover, this proposal will help in the implementation of contracts through staff properly, and avoids the customer frauds and mistakes.

\subsection{Limitations}

There are some limitations that may effect on the proposal which submitted by researchers:

a. Weakness of knowledge and experiences.

b. Weakness of control of huge services in many branches.

c. Frauds and trickery. 
d. Quickly change of contracts as a result of rapid trading on the computer and the Internet. Documentation of contracts would not follow this fast dealing. Internet gives customer the way to make deal from any location and any time (Peter and Sylvia, 2008)

e. Weak commitment in Islamic accounting standards in the Jordanian Islamic banks.

\subsection{Recommendations}

The researchers recommended that there is an urgent need to apply the proposal which submitted from them (The proposed model of relationship between EA and SSB). The researchers believed that it is appropriate tool for each of the EA and the SSB to carry out their duties as required.

\section{REFERENCES}

Ahmed, Fatma \& Hussainey, Khaled, (2015),Conversion into Islamic Banks: Jurisprudence, Economic and AAOIFI Requirements, European Journal of Islamic Finance, European Center for Islamic Finance, Universitàdegli Studi di Torino, Vol. 3, p1, http://www.ojs.unito.it/index. php/EJIF/article/view/1111/1186

Aisah, N., Muhammadun, Z., Shahimi, S., and Shaffii, Z., (2015), Competency of Shariah Auditors in Malaysia: Issues and Challenges, Journal of Islamic finance, Institute of Islamic Banking and Finance, International Islamic University Malaysia, 4(1), p1.

Atmeh, Muhannad \& Abu Serdaneh, Jamal,(2012), A Proposed Model for Accounting Treatment of Ijarah, Published by Canadian Center of Science and Education, International Journal of Business and Management; 7(18), p 49 http://www.ccsenet.org/journal/index.php/ijbm/article/ viewFile/17370/13505

Elsiefy, Elsayed, (2013), Comparative analysis of Qatar Islamic banks performance versus conventional banks before, during and after the financial crisis, International journal of business and commerce, 3(3), p11.http://www.ijbcnet.com

Islamic International Arab bank (Annual Report), (2014), p 14 and 15

http://www.iiabank.com.jo/Portals/0/Islamic\%20Arab\%20Bank\%20Annual\%20Arabic\%202014\%20 P2.pdf

Jordan Islamic bank (Annual Report), (2015), Pages 80, 84 and 85.

http://www.jordanislamicbank.com/usersfilenew/folder/files/report2015s2.pdf

Munusamy, J., Chelliah, S.\&Mun, H., (2010), Service Quality delivery and its Impact on customer satisfaction in the banking sector in Malaysia, International journal of Innovation, Management and technology, vol. 1, no.4, p 398. http://www.ijimt.org.

Mulyany, Ratna and Hameed, Shahul, (2009), Shariah Audit for Islamic Financial Institutions (IFIs): Preceptions of Accounting Academicians, Audit Practitioners and Shariah scholars in Malaysia, Tenth Asian Academic Accounting Association Annual Conference, Istanbul, Turkey, https://www.researchgate.net/publication/299512294.

Nazzal, Abdullah, (2006), The Effect of Sharia Controls on Development of Banking Services-A Theoretical Empirical Study, Ph.D. thesis, College of Banking and Financial Sciences, Amman, Jordan, $\mathrm{p} 70$.

Perry ,F.V. \& Rehman,S. S., (2011), Globalization of Islamic Finance: Myth or Reality?, International Journal of Humanities and Social Science, India, 1(19), p117 http://www.ijhssnet.com/journals/ Vol_1_No_19_December_2011/12.pdf

Rose, Peter S. and Hudgins, Sylvia, (2008) ,Bank Management and Financial Services, seventh edition, Mc Gram Hill, New York, USA, p117.

Sadique, Muhammad A., (2009), Profit and Loss Allocation among Islamic Bank and Client Partner in Equity Financing: Practice, Precepts and Alternatives, Journal of Islamic Economics., 22(1), p145.

Schroeder ,R. G., Clark ,M. W. and Cathey,J.M., (2011), Financial accounting theory and analysis: text and cases, tenth edition, John Wiley and Sons INC, Hoboken, USA, pp586-587. 


\section{AUTHORS' BIOGRAPHY}

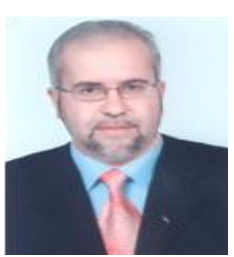

Dr. Raed J.Jaber, is Assistant Professor in the Accounting Department at the Faculty of Economics in Zarqa University, Jordan from 2013 to date. He was Vice President for Financial and Administrative Affairs in the Arab Academy for Banking and Financial Sciences, Amman from 2008-2013. Also, He was employee in several jobs in financial and administrative issues in the Arab Academy F.B.A.F.S from 1992-2008.

$\mathrm{He}$ Got his $\mathrm{PhD}$ in Accounting (Auditing) from The Arab Academy for Banking and Financial Sciences, Amman, Jordan, 2010. He has published several research papers in Auditing, Corporate Governance, Islamic Accounting and Internal Control System .He is now preparing article in the budgets of programs and performance in governmental accounting. Dr. Jaber participated in many Boards and Committees within his work in the Arab Academy and Zarqa University.

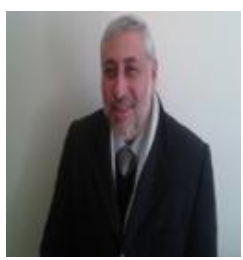

Dr. Abdullah I. Nazal, is Associate Professor in Department of finance and banking at the Faculty of Economics in Zarqa University, Jordan. In 2007 - 2008 he worked as Faculty member in Arab Academy of Finance and Banking within Yemen branch. In 2009 until now he is working in Zarqa University. He Shared in conferences and had published searches and books whether in Arabic or English, locally or internationally. The interested studying for him is finance engineering in general budget, traditional companies and Islamic companies. 